\title{
Taking a Marked Stance through Evaluative Lexical Items: A Study of Selected Features of Obama's and Trump's Inaugural Speeches
}

\author{
Wyrażenie swojego szczególnego stanowiska \\ przy użyciu wartościujących środków językowych: \\ studium wybranych cech językowych przemówień inauguracyjnych \\ Baracka Obamy i Donalda Trumpa
}

Arkadiusz JANCZYŁO ${ }^{1}$

Ateneum-Szkoła Wyższa w Gdańsku

\begin{abstract} with all its derivative forms as used in the two speeches. pragmatic effect, text genre

\section{Streszczenie}

1 https://orcid.org/0000-0002-2172-4791

Ateneum - University in Gdańsk, Neophilological Dept.

a.janczylo@ateneum.edu.pl
\end{abstract}

The paper presents an analysis of Obama's and Trump's inaugural addresses with a view to evidencing how language can be manipulated and also reveal the speaker's political and ideological stance through the use of marked and evaluative lexical items. The language sample selected for analysis contains personal pronouns and possessive adjectives 'you, your, we, us, our, ours, ourselves, they, their, them, themselves', determiner 'other' and the term 'America'

Keywords: discourse analysis, evaluative language, ideology, lexical items, political discourse,

Artykuł przedstawia analizę przemówień inauguracyjnych Baracka Obamy i Donalda Trumpa. Celem analizy jest wykazanie, w jaki sposób językiem można manipulować i w jaki sposób język 
ujawnia polityczne i ideologiczne stanowisko mówcy, np. przy użyciu rejestru specjalnego oraz wartościujących środków językowych. Na wyrażenia poddane analizie w niniejszym artykule składają się angielskie zaimki osobowe „you, your, we, us, our, ours, ourselves, they, their, them, themselves”, zaimek „other” oraz termin „America” wraz ze wszystkimi jego derywatami morfologicznymi zastosowanymi w omawianych przemówieniach.

Słowa kluczowe: analiza dyskursu, dyskurs polityczny, efekt pragmatyczny, ideologia, język wartościujący, środki językowe, typ tekstu

\section{Introduction}

Political discourse is famous for its ideological content whose realisation occurs on a multitude of textual, semantic and pragmatic levels. Since its role is to persuade listeners and/or readers to various political ideas and agendas, at the same time dissuading them from others, it is only natural that political language is tinted ideologically. To that end, the linguistic means are meticulously selected and analysed before a speech is ready for delivery; in particular, presidential inaugural speeches, whose primary function is to bring people together as one nation again after the political battle is won by one candidate leaving the other behind. Such speeches are typically characterised by a significant evaluative and emotional linguistic content, rather enthusiastic, encouraging and highly motivational.

Following often arduous periods of presidential campaigns, the society needs to be reunited from its political divide and there is hardly a better tool than the inaugural speech. It creates an opportunity for people to feel like they belong together yet again in order to face the next presidential term regardless of the fact whether they voted for or against the elect. The common goal is, after all, to make the country and its people stronger and richer by the end of the term. Thus the message of the speech is sturdily grounded in patriotic colours, history and culture in order to sell well to the public through reference to shared values and goals to achieve.

This paper aims to analyse two presidential inaugural addresses delivered by the previous two American presidents: Barack Obama (2009) and Donald Trump (2017), on 20th January $2009^{2}$ and 20 January $2017^{3}$ respectively. The primary assumption is that both speeches betrayed the authors' ideological slanting and showed the direction in which their political road was being paved. In hindsight, the way the two presidencies developed made it evident

\footnotetext{
2 http://obamaspeeches.com/P-Obama-Inaugural-Speech-Inauguration.htm

${ }^{3}$ https://www.americanrhetoric.com/speeches/donaldjtrumpinauguraladdress.htm
} 
how truthful Obama and Trump remained to the democratic and republican ideals presented in their speeches. The analysis will investigate the speeches primarily within their lexical levels regarding the use of personal pronouns, personal adjectives, determiner 'other' and the term 'America' in all its derivative forms as delivered to the public.

\section{Methodology}

In order to provide for an informative argument, several linguistic concepts will be applied in the paper. Some come directly from the study of language, others cross over between language and sociology or language and psychology. It would be helpful to offer some explanation as to which concepts make grounds for analysis and why.

First, the analysis here is placed in the broad context of linguistics, with a particular emphasis on sociolinguistics, and discourse analysis with its many levels and aspects. The two speeches will be analysed discoursally at the lexical level, from the point of view of text genre, regarding their ideological content and structure, participants, medium, intention and strategy (Johnstone, 2010). Also, the material will be analysed through Searle's (1979) concepts of indirect speech acts as well as illocutionary acts for its pragmatic structure and effect. Of special interest is also the evaluative effect of the selected lexical items as used in the text. The concept of evaluation applied here is taken from Hunston \& Thompson (2000, p. 6).

The two speeches selected for analysis are understood to belong to the same genre of political speech. The genre stands for extensive opportunities for manipulative language use, where sociological, cultural and psychological aspects are inherently imbedded through language and utilised to achieve a certain emotional and ideological effect in text recipients. The inaugural addresses delivered by the two presidents had a special function to unite the American nation, otherwise politically divided along an ideologically powerful border between the democratic and the republican. As is the case with every elected president in any republic in the world, the inauguration is a tool used to unite supporters and opponents along a common cause. As a result, such speeches are typically grounded in and refer to values that the whole society shares as their historical, philosophical, cultural and ideological foundations where the traditions, ethics and laws of the land are rooted. Consequently, language - being the main 
means through which people experience life, reality and the world around will reflect those values.

The language of the two speeches is rich in various references to American values. However, for the purposes of this paper only selected evaluative words and phrases are subject to analysis. The material contains personal pronouns and possessive adjectives 'you, your, we, us, our, ours, ourselves, they, their, them, themselves', determiner 'other' and the term 'America' with all its derivative forms which appear in the text. The motivation behind choosing these lexical items comes from the evaluative nature of the phrases in which they appear. Thus, they produce specific pragmatic effects with their illocutionary evaluative force.

After Hunston \& Thompson (2000, p. 6), the evaluative effect is understood here as the speaker's opinion reflecting the value system in the American society. The evaluative aspect of the language helps the speaker organise their text, and furthermore to establish a strong emotional and ideological connection between the speaker and the hearer. This in turn produces a sociological and psychological effect upon the listener evoking a sense of belonging to a community, one of the natural needs of every human being. Additionally, the shared values referenced in the speeches create an emotional effect whereby the society feels its foundations are anchored in stable and eternal premises.

\section{Analysis}

\section{General remarks}

This section presents an analysis of the selected language items; namely, personal pronouns and possessive adjectives 'you, your, we, us, our, ours, ourselves, they, their, them, themselves', determiner 'other' and the term 'America' with all its derivative forms which appear in the text. The material under analysis excludes personal pronouns ' $\mathrm{I}$ ' and 'me' as well as possessive pronoun and adjective 'my' and 'mine'. The decision to omit them was based on the fact that the nature of the analysis here is grounded in duality, or in other words division that is common in the political discourse between 'us' and 'them'. Collective identity is effectively built around ideals which bind most or all members of the society, and excludes values which do not fit or belong in its philosophy, culture and/or ethics. Thus the analytical categories applied here reflect this division.

The analysis is twofold with the first part relating to the differences in the number of ways the idea of 'us' is addressed as opposed to the 'them' 
in both speeches and what effect is eventually achieved (Fig. 1). Whereas the second part deals only with the way the concept of 'Them' is presented in the two texts, which also accounts for different resultant effects aimed for by Obama and Trump.

\section{Part 1 - Total, Us, Not us, Ideals}

Figure 1 below presents numerical data regarding the selected lexical items from both speeches. Each lexical item is presented separately according to four categories applied in the analysis, which are:

The Total category displays the total number a particular lexical item is used in the given speech.

The Us category displays positive evaluation and accounts for all the members being together or belonging to the same social group. It shows how many times out of the Total the given lexical item is used to refer to the community and/or society, people or otherwise - whatever it is that constitutes us as a group, including anything shared within the group. This category includes all the lexical items selected for analysis as evidenced in the broader context of the speeches.

The Them category displays negative evaluation and accounts for all the entities referred to this way as being outside the society and/or community. It shows how many times out of the Total the given lexical item is used to refer to such entities, people or otherwise - whatever it is that constitutes them as a group, including anything shared within that community.

The Ideals category indicates the historical dimension from which come the ideals that the society/community is built upon. Ideals that have enable the establishment of collective identity of the given group. The category also shows how many times out of the Total the given lexical item is used to refer to such ideals that help constitute the group's identity. 


\begin{tabular}{|c|c|c|c|c|c|c|c|c|}
\hline & \multicolumn{4}{|c|}{ Obama’s speech (Obama, 2009) } & \multicolumn{4}{|c|}{ Trump's speech (Trump, 2017) } \\
\hline & 胥 & 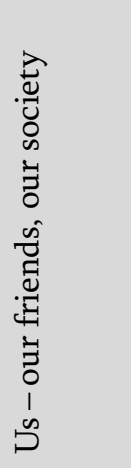 & 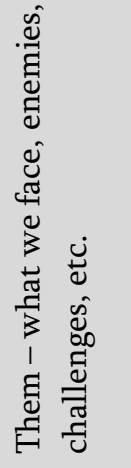 & 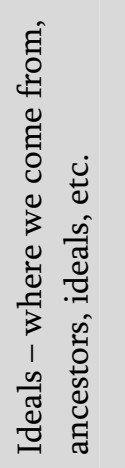 & 뀸 & 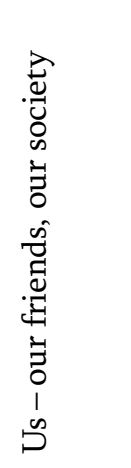 & 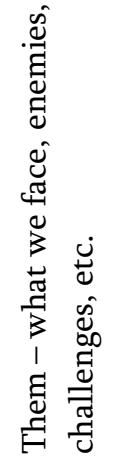 & 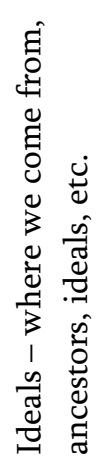 \\
\hline You & 14 & 5 & 9 & & 8 & 8 & & \\
\hline Your & 3 & & 3 & & 11 & 11 & & \\
\hline We & 61 & 61 & & & 50 & 50 & & \\
\hline Us & 14 & 14 & & & 2 & 2 & & \\
\hline Our & 66 & 66 & & & 48 & 48 & & \\
\hline Ours & 1 & 1 & & & 0 & & & \\
\hline Ourselves & 2 & 2 & & & 0 & & & \\
\hline They & 17 & 5 & 5 & 7 & 5 & 4 & 1 & \\
\hline Their & 10 & 3 & 3 & 4 & 11 & 9 & 2 & \\
\hline Them & 4 & 1 & 2 & 1 & & & & \\
\hline Themselves & 1 & 1 & & & 1 & 1 & & \\
\hline Other & 1 & & 1 & & 7 & 1 & 4 & \\
\hline America & 15 & 15 & & & 40 & 40 & & \\
\hline \multirow{2}{*}{ TOTALS } & 209 & 174 & 23 & 12 & 181 & 174 & 7 & \\
\hline & & $83.25 \%$ & $11.01 \%$ & $5.74 \%$ & & $96.13 \%$ & $3.87 \%$ & $0 \%$ \\
\hline
\end{tabular}

Fig. 1.

As we look at the numbers in Fig. 1, certain similarities emerge. Overall, Obama's and Trump's speeches devote most attention to the Us concept (slightly over $83 \%$ and $96 \%$ respectively) in comparison to the Them (slightly over $11 \%$ and under $4 \%$ respectively) and Ideals concepts (under $6 \%$ and slightly over $0 \%$ respectively). Another similarity is that the lexical items used for particular categories are largely the same. This, however, is where the similarities end.

For instance, the Them category excludes all lexical items relating to the pronoun 'we', 'themselves' and the term 'America'. The reason for this is evident in the texts, as in terms of political identity construction of a person is one of us then they are not one of them. The pronouns 'themselves', on the other hand, is used reflexively to refer to the American society in both 
speeches. Finally, the term 'America' with all its derivative forms refers exclusively to the whole American society and by its very nature includes every American and everything American.

The pronoun 'they' with its derivatives is included in the Ideals category only in Obama's speech. They are used primarily to reflex back to the American values whenever they are mentioned again and/or repeated. In the context of Trump's speech, American values are addressed directly by their names and are not referred back again later in the text. It can be partially explained by the simple language in Trump's speech, and stand in obvious juxtaposition to Obama's eloquence and master speaking skills.

Another difference is in the percentages for the Us category in the two texts. It is evident that Trump focused almost exclusively on the American society (nearly $12 \%$ more references are made than in Obama's speech). The fact was later also reflected in Trump's foreign policy and international affairs, where he largely antagonised and isolated from America's neighbours and allies. The speech was a clear premonition of the way he was going to do international politics. On the other, Obama's speech may not display an overwhelming slant towards international affairs either. However, he made a much clearer bow towards America's international connections nearly four times more than Trump.

Another interesting finding is the use of the determiner 'other' in both speeches. Obama used it only once in the Them category, whereas Trump used it five times, one of which relates to the $\underline{U s}$ category and four relate to the Them category. Trump made a reflexive reference using the phrase 'each other' to illustrate how Americans are able to help 'each other', and as a result applied a rhetorical device to increase the 'togetherness' effect of his speech on this particular occasion. This, however, did little to improve that effect globally in his speech.

Overall, Obama's speech comes across as significantly more inclusive socially and internationally, delineating more chances to repair rather than deepen the political rift in the American society. The global effect of Trump's text, on the other hand, seems to perpetuate the political crack that helped him win the election. By failing to make meaningful references to America's international links he succeeded in emphasising America's isolation from the rest of the world. 


\section{Part 2 - Them: Friendly vs Confrontational}

This part of analysis focuses in more detail on the Them category (see Fig. 1 above). Three categories have been delineated for this part of analysis (see Fig. 2 below):

The Total category shows the total number of references to 'them' in the given speech and the relevant percentage it makes in the whole speech.

The Friendly category shows how many times out of the Total the given lexical items are used to refer to foreign entities in a friendly manner.

The Hostile category shows how many times out of the Total the given lexical items are used to refer to foreign entities in a hostile manner.

The data relate to the manner in which both Obama and Trump do make references to entities from the outside of America. The references are be broadly evaluated as either friendly or hostile. The references concern foreign entities, foreigners, but also problems and challenges that America faces both international as well as domestic ones. The term 'friendly' implies a peaceful approach and/or extending international help to less fortunate regions of the world. The term 'hostile', however, concerns warnings, threats readiness and willingness to take decisive military and/or economic action if necessary against foreign entities.

\begin{tabular}{|c|c|c|c|c|c|c|}
\hline & \multicolumn{3}{|c|}{$\begin{array}{l}\text { Obama's speech } \\
\text { (Obama, 2009) }\end{array}$} & \multicolumn{3}{|c|}{$\begin{array}{l}\text { Trump's speech } \\
\text { (Trump, 2017) }\end{array}$} \\
\hline & Total 'Them' & Friendly & Hostile & Total 'Them' & Friendly & Hostile \\
\hline $\begin{array}{l}\text { You - other } \\
\text { nations/enemies }\end{array}$ & 9 & 3 & 6 & & & \\
\hline $\begin{array}{l}\text { Your - other } \\
\text { nations/enemies }\end{array}$ & 3 & 1 & 2 & & & \\
\hline $\begin{array}{l}\text { They - what we } \\
\text { face, enemies, } \\
\text { challenges, etc. }\end{array}$ & 5 & & 5 & 1 & & 1 \\
\hline $\begin{array}{l}\text { Their - what we } \\
\text { face, enemies, } \\
\text { challenges, etc. }\end{array}$ & 3 & & 3 & 2 & & 2 \\
\hline $\begin{array}{l}\text { Them - what we } \\
\text { face, enemies, } \\
\text { challenges, etc. }\end{array}$ & 2 & & 2 & & & \\
\hline Other - not us & 1 & 1 & & 4 & & 4 \\
\hline TOTALS & $23 / 209$ & $5 / 23$ & $18 / 23$ & $7 / 183$ & & $7 / 7$ \\
\hline & $11.01 \%$ & $21.74 \%$ & $78.26 \%$ & $3.83 \%$ & & $100 \%$ \\
\hline
\end{tabular}

Fig. 2. 
As mentioned in Part 1 above, Obama's addresses to foreign entities constitute slightly over $11 \%$ of the references under analysis in this paper, whereas in Trump's speech they make under $4 \%$. What is even more interesting to observe in the collected lexical data is that of the two texts Trump's speech contains no 'friendly' addresses towards foreign connections. His were $100 \%$ hostile threats and warnings which can be generally interpreted that America will take what it thinks it deserves or will do what it thinks is right. Obama made 'friendly' references to America's international connections on five occasions out of 23 international addresses (slightly under 22\%), making the remaining 18 'hostile' (a little over 78\%).

In Obama's speech the scale is also evident and unambiguously biased towards hostility. However, looking at the expression aspect, his hostile addresses sound rather cloaked and mild, albeit decisive in comparison with Trump's simple and direct language. The idea behind such a significant bias towards the foreign can be explained by the fact that ethnicity constitutes a key factor in identity construction, and ethnicity comes from the environment where one lives (McGuire et al., 1978; Schneider, 1988, p. 125).

\section{Conclusions}

Political speeches are ideologically laden texts which, similarly to other political texts, serve persuasion purposes. Persuasion in presidential inaugural addresses specifically aim at organising the whole society around the presidentelect and motivating them to work collectively towards a common goal. This effect can be particularly challenging to achieve in the context of presidential election as the society will normally be strongly divided on account of the 'right' or 'wrong' candidate winning. Therefore the inaugural speech has an additional function to bury political differences between president-elect's supporters and opponents.

Consequently, the language the speech is written in will play a special role and as such is usually carefully chosen and adjusted on many levels: lexical, textual, ideological, evaluative, sociological, psychological, etc. Obama's and Trump's speeches selected for analysis in this paper show clearly different approaches to that end, and constituted blueprints for the presidents' political road forwards.

Obama and Trump both devote most of their attention to the Us category (slightly over $83 \%$ and $96 \%$ respectively) in comparison to the Them (slightly over $11 \%$ and under $4 \%$ respectively). This is achieved through largely 
the same lexical items. The 'us' versus 'them' distinction is a powerful political manipulation tool due to its dichotomous nature; who is not one of 'us' is automatically one of 'them'. As a result, in the data provided here, the Them category excludes all lexical items relating to the pronoun 'we' as swell as the term 'America' with all its morphological variations. The latter refer to the whole American society and by definition include every American.

American values are addressed in both speeches, but the Ideals category in Obama's speech reflects back to them whenever they are mentioned again and/or repeated, which makes Obama's expression more eloquent and rhetorical. Trump's speech, however, simply labels American values directly and does not refer back to them later. This simplicity of expression seems to have struck a chord with those circles of the general electorate who speaks simple language themselves.

What is also plainly important for Obama and is evident in his speech is a sizeable slant towards international affairs. He sends a positive signal to America's international connections whereas Trump failed to do so completely.

Overall, Obama's speech presents a significantly more inclusive stance socially and internationally. He aims to repair the political rift in the American society. The global effect of Trump's text, on the other hand, rather perpetuates the political crack among Americans and, additionally emphasised America's isolation from the rest of the world.

\section{REFERENCES}

Hunston, S., \& Thompson, G. (2000). Evaluation in text: authorial stance and the construction of discourse. Oxford: Oxford University Press.

Johnstone, B. (2010). Discourse Analysis. Oxford: Blackwell Publishing.

McGuire, W. J., McGuire, C. V., Child, P., \& Fujioka, T. (1978). Salience of Ethnicity in the Spontaneous Self-Concept as a Function of One's Ethnic Distinctiveness in the Social Environment. Journal of Personality and Social Psychology, 36(5), 511-520. DOI: $10.1037 / / 0022-3514.36 .5 .511$

Obama, B. (2009). Obama Inaugural Address. Washington, D.C., http://obamaspeeches.com/ P-Obama-Inaugural-Speech-Inauguration.htm [1 Aug 2021]

Searle, J. R. (1979). Expression and Meaning: Studies in the Theory of Speech Acts. Cambridge: Cambridge University Press.

Schneider, D. J. (1988). Introduction to Social Psychology. San Diego, New York, Chicago, Austin, Washington D.C., London, Sydney, Tokyo, Toronto: Harcourt Brace Jovanovich.

Trump, D. (2017). Donald J. Trump Presidential Inaugural Address. Washington, D.C., https:/www.americanrhetoric.com/speeches/donaldjtrumpinauguraladdress.htm [1 Aug 2021] 